\title{
„Althea” Felicjana Faleńskiego - MIĘDZY DZIEWIĘTNASTOWIECZNYM DRAMATEM A ORATORIUM
}

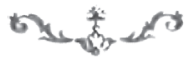

$\mathrm{W}$ KSIĄŻCE POŚWIĘCONEJ rozwojowi tragedii polskiej drugiej połowy XIX wieku Marek Dybizbański pisze, że współczesne prace literaturoznawcze w mniejszym lub większym zakresie utrwalają tezę o niewystarczającym zainteresowaniu twórców postyczniowych estetyką tragedii ${ }^{1}$. Badacz we wprowadzeniu do swojej monografii zaznacza:

Dźwigała zresztą [epoka postyczniowa - Ł.T.] to piętno zawsze, co poświadczają diagnozy formułowane przez ówczesnych krytyków (Choińskiego, Kaszewskiego i innych). Co prawda Marian Szyjkowski w latach dwudziestych XX w. prezentował Dzieje nowożytnej tragedii polskiej jako proces ciągły, ale w badaniach powojennych między opracowaniami chronologicznie określonych form tragedii neoklasycystycznej (autorstwa Dobrochny Ratajczakowej) i młodopolskiej (w wykonaniu Ireny Sławińskiej) zadomowiła się wymowna luka, która ostatnio zyskała nawet dobitne uzasadnienie - i to z podwójnej perspektywy jednocześnie, bo w dwóch syntezujących artykułach wydrukowanych $\mathrm{w}$ jednym pokonferencyjnym tomie. Włodzimierz Szturc rozważa tam przyczyny zaniku tragedii w wieku osiemnastym i ostatecznego jej upadku w dziewiętnastym, natomiast Wojciech Gutowski charakteryzuje moder-

1 M. Dybizbański, Tragedia polska drugiej połowy XIX wieku - wzorce i odstępstwa, Poznań 2009, s. 9. Na temat dziewiętnastowiecznej tragedii - zob. też cytowane przez badacza prace: I. Sławińska, Tragedia w epoce Młodej Polski. Z zagadnień struktury dramatu, Toruń 1948; Polska tragedia neoklasycystyczna, wyb., wstęp i oprac. D. Ratajczakowa, Wrocław 1989; W. Szturc, Tragedia i jej zanikanie w literaturze polskiej XVIII i XIX wieku. Kilka pytań i kilka odpowiedzi, w: Problemy tragedii i tragizmu. Studia i szkice, red. H. Krukowska i J. Ławski, Białystok 2005; W. Gutowski, Młodopolski palimpsest tragiczności, w: jw. 
nistyczne doświadczenie tragizmu w opozycji do „nietragicznych paradygmatów światopoglądowych” dwóch współczesnych epok - romantycznego mesjanizmu i pozytywistycznego organicyzmu. ${ }^{2}$

Przypomnijmy, że już lata dwudzieste XIX wieku były zapowiedzią kryzysu narodowej tragedii opartej na klasycystycznej teorii dramatu. Twórcy romantyczni chętnie sięgali po wzorce dramatyczne wypracowane przez Williama Shakespeare'a oraz Friedricha Schillera, łamiące antyczne zasady czystości rodzajowej i gatunkowej. Popularnym gatunkiem stała się - mająca swoje korzenie w oświeceniowym sentymentalizmie - drama, o której Jarosław Maciejewski pisał: „Upowszechniała melodramatyczny schemat fabularny, mieszała nastroje patetyczne i komiczne, zdarzenia wielkie i błahe, a jej fabuły działy się nie tylko na dworach królewskich; częściej w środowiskach «niskich» i egzotycznych [...]" ${ }^{3}$. Zainteresowanie tragicznością wzrosło wyraźnie na przełomie XIX i XX wieku w obliczu młodopolskiego dekadentyzmu i nastrojów pesymizmu przemieszanego z lękiem wobec przyszłości. Tragedia modernistyczna, jak pisze Dybizbański w cytowanej pracy, ogniskowała się wokół problematyki psychologicznej i egzystencjalnej. Człowiek neoromantyczny albo stawał się syntezą emocji i przesądów, albo wchodził $\mathrm{w}$ konflikt $\mathrm{z}$ prawem naturalnym a własnymi potrzebami, które nie miały wiele wspólnego z normami etyczno-moralnymi ${ }^{4}$.

Powyższe konteksty warto brać pod uwagę, czytając Altheę (1875) Faleńskiego, którą należy również sytuować na tle dziewiętnastowiecznej, modernistycznej refleksji nad tragizmem, wyrastającej, jak wiemy, przede wszystkim z recepcji myśli Friedricha Nietzschego. W Narodzinach tragedii, albo Grekach i pesymizmie (1872) filozof uznał, że ekstatyczna dionizyjskość, łączona z melicznością, dominowała przy kształtowaniu się formuły tragiczności ${ }^{5}$. Cielesność stanowiła dla Nietzschego najistotniejszy elementem egzystencji, na której niejako wtórnie nadbudowywała się sfera duchowości i intelektu. Idąc w ślad diagnoz Arystotelesa, wyrażonych w Poetyce, uważał, że tragedia ma swoje źródła w starogreckiej liryce dytyrambicznej. Ten rodzaj tragiczności byłby związany z rolą fatum, działaniami sił nadprzyrodzonych oraz nieustannie kształtującą się istotą człowieka, który w toku egzystencji nieustannie „stwarza się”.

2 M. Dybizbański, dz. cyt., s. 9-10.

3 J. Maciejewski, Dramat, w: Słownik literatury polskiej XIX wieku, red. J. Bachórz, A. Kowalczykowa, Wrocław 2009, s. 168.

4 M. Dybizbański, dz. cyt., s. 10.

5 Zob. F. Nietzsche, Narodziny tragedii, albo Grecy i pesymizm, przekł. i przedm. B. Baran, Warszawa 2009. 
Czytając Altheę Faleńskiego, warto również mieć w pamięci inny typ tragiczności, opartej na bólu istnienia i woluntaryzmie, który można odnaleźć w pismach Arthura Schopenhauera. Filozof, dokonując diagnozy przyczynowości świata, pisał:

[...] świat ze wszystkim, co w nim tkwi, objawia się nam jako bezcelowa i dlatego niepojęta igraszka wieczystej konieczności, niezgłębionej i nieubłaganej Ananke. Coś, co nas razi, ba, oburza w tym poglądzie na świat, można jednak usunąć wtedy tylko, jeśli się przyjmie, że każda istota na tym świecie jest z jednej strony zjawiskiem, określonym nieuchronnie przez prawa rządzące zjawiskami, z drugiej zaś jest sama w sobie wolą, i to po prostu wolną wolą, gdyż każda konieczność powstaje wyłącznie dzięki formom, które należą tylko do zjawiska, mianowicie dzięki regule podstawy dostatecznej w jej rozmaitych postaciach; ale takiej woli musi też przysługiwać samodzielność [Aseität], gdyż będąc wolna, tj. jako rzecz sama w sobie, która nie podlega regule postawy dostatecznej, nie może zależeć ani w swym bycie, ani w swej istocie od czegoś innego. Tylko takie założenie gwarantuje tyle wolności, ile potrzeba jako przeciwwagi dla nieuniknionej, bezwzględnej konieczności, która rządzi biegiem świata. ${ }^{6}$

Tragizm schyłku XIX wieku zostaje zatem dopełniony socjologizmem i historyzmem. Klęska człowieka lub całego narodu wiąże się ze specyfiką uwarunkowań historycznych, które nie tworzą dogodnych warunków rozwoju i ekspresji siły duchowej.

W drugiej połowie XIX wieku zainteresowaniem zaczęła cieszyć się tragedia moralizatorska, odnawiająca antyczny wzorzec gatunkowy ${ }^{8}$. Ewa Nawrocka, pisząc o kategorii tragizmu w kontekście literatury postyczniowej, zauważa:

Ze względów cenzuralnych, a także w intencji uprzystępnienia wiedzy historycznej autorzy dramatów sięgają do tematów z dawnych dziejów Polski (Szujski, A. Bełcikowski, Urbański), z historii starożytnej (Faleński, Świętochowski) lub egzotycznych tematów orientalnych (J. Łętowski). Były to tragedie w większości mało literacko wartościowe, retoryczne, niedźwigające istoty tragizmu. Powstały również przesycone tragizmem dramaty nawiązujące tematycznie do przebiegu i do klęski powstania styczniowego, odwołujące się do wzorca Nie-Boskiej komedii i dramatu romantycznego (m.in. L. Sowiński, A. Asnyk). ${ }^{9}$

W kontekście twórczości dramatycznej Felicjana Faleńskiego trudno zgodzić się z przywołanym wyżej stwierdzeniem badaczki, że ówczesna drama-

6 A. Schopenhauer, Świat jako wola i przedstawienie, przeł. J. Garewicz, t. 1, Warszawa 2009, s. 453-454. Zob. też: Słownik myśli filozoficznej, red. M. Kuziak, S. Rzepczyński, T. Tomasik, D. Sikorski, T. Sucharski, Bielsko-Biała 2004, s. 257-258.

7 Zob. E. Nawrocka, Tragizm, w: Słownik literatury polskiej XIX wieku, s. 962.

8 Tamże.

9 Tamże. 
turgia, wykorzystująca kostium historyczny, nie miała dużej wartości literackiej. Althea Faleńskiego to przykład dramatu, w którym doskonale widać neoromantyczną fascynację psychologicznymi motywacjami postaci. Przedstawiona tutaj próba analizy formuły tragiczności w dramacie autora $\mathrm{Me}$ andrów zwraca szczególną uwagę na pojawiającą się w dziele warstwę muzyczną, zbliżającą Althę do oratorium. Mitologiczna opowieść o łowach kalidońskich posłużyła Felicjanowi tylko za tło dogłębnej analizy psychologicznej bohaterów. Althea, zachowując strukturalne elementy greckiej tragedii, jest bliska modernistycznym diagnozom światopoglądowym, stawiającym w centrum uwagi sferę ludzkiej psychiki i uwikłanie człowieka w wolę mocy, instynktu determinującego wszelkie działania i egzystencję.

Althea miała swój pierwodruk w czasopiśmie „Bluszcz” w 1875 roku. Utwór zadedykował Faleński przyjacielowi z lat młodości - Kazimierzowi Kaszewskiemu. W 1898 roku tragedia została włączona do drugiego tomu jego utworów dramatycznych, zajmując miejsce obok Floryndy i Franczeski $z$ Rawenny ${ }^{10}$.

Aktywność na polu dramatycznym była niejako próbą przełamania przez Faleńskiego mitu o niedopasowaniu jego twórczości lirycznej do warunków epoki, co stale akcentowano w pracach krytycznych i historycznoliterackich. Takie diagnozy znajdziemy między innymi u Wiktora Przecławskiego i Marii Grzędzielskiej ${ }^{11}$. Czyniono analogie do tragicznej egzystencji Cypriana Norwida, określając jednocześnie autorów urodzonych około 1820 roku mianem straconego pokolenia. Oczywiście, część twórczości Faleńskiego naznaczona jest piętnem nostalgii, czasem nawet żalu i rozpaczy, ale „szufladkowanie” i „etykietowanie” tak wszechstronnego autora, jest błędem metodologicznym. Dbałości Felicjana o formę nie należy postrzegać jako przejawu jedynie inspiracji parnasistowskiej. Zjawisko ma szerszą motywację artystyczną.

Sięgając w Althei po motywy mitologiczne, Felicjan wyraźnie pokazał, że ideowo bliskie mu były wzorce antyczne. Warto w tym miejscu zacytować opinię Urszuli Kowalczuk, która zastanawiając się nad wpływem antyku grecko-rzymskiego na kształt twórczości Faleńskiego, zauważa:

Rozmaitość dziewiętnastowiecznych fascynacji i zniewoleń antykiem jest odzwierciedleniem procesu dynamizowania się paradygmatu kulturowego [...]. Kod antycz-

10 Zob. [F. Faleński], Felicjana utwory dramatyczne, t. 2, Kraków 1898.

11 Por. W. Przecławski, Felicjan Medard Faleński. Żywot i dzieła, Poznań 1922; M. Grzędzielska, Studia o Felicjanie Faleńskim. Streszczenie pracy habilitacyjnej, Lublin 1963. 
ny sprzyja artystycznym poszukiwaniom, ale też służy do mówienia o problemach teraźniejszości, współtworzy refleksję nad pojęciami rodzimości i narodowości. ${ }^{12}$

Antyk staje się zatem dla Felicjana przestrzenią porozumienia ze współczesnością oraz swoistym teatrem dziejów, w którym pewne motywy, zdarzenia i psychologiczne motywacje mają swoje stałe miejsce. Warto jednak podkreślić, że wszystkie te elementy są modelowane przez czas, przestrzeń i moment dziejowy.

Omawiany dramat Felicjana został dobrze przyjęty przez środowisko literackie przełomu XIX i XX wieku. Józef Kotarbiński w pracy Pogrobowiec romantyzmu. Rzecz o Stanisławie Wyspiańskim, pisał: „Pod względem polotu, energii i piękności języka niewątpliwie wyżej stoi [niż Meleager Wyspiańskiego - Ł.T.] osnuta na tym samym podaniu tragedia Faleńskiego Althea, zbudowana harmonijnie, szeroko, błyszcząca wirtuozerstwem i plastyką formy - znana jednak tylko małej liczbie literackich smakoszów" ${ }^{13}$.

Przypomnijmy, że mitologiczna opowieść o próbach zabicia dzika pustoszącego pola kalidońskie, którego głowę Meleager ofiarował pięknej Atalancie, była chętnie wykorzystywana przed twórców dziewiętnastowiecznych. Warto w tym miejscu przywołać wspomniany już dramat Wyspiańskiego Meleager (1899) oraz dzieło Algernona Charlesa Swinburne'a Atalanta w Kalidonie (1865). Maria Grzędzielska, zestawiając wymienione tragedie, pisze:

W porównaniu z pokrewnymi tematycznie tragediami Swinburne’a i Wyspiańskiego uderza w Althei pewna asceza koncepcji. Meleager, o którego życie przecież chodzi, nie ukazuje się żywy, usunięty został król Kalidonu Oineus i obecni u Swinburne'a bracia Althei. Wysunięta została na czoło królowa Althea, mniemająca, że wolno jej gardzić bogami, skoro od jej woli tylko ma zależeć życie Meleagra. [...] Według mitu Althea spaliła głownię, w którą zaklęte zostało życie syna, ponieważ chciała pomścić zamordowanych przez niego swoich braci. ${ }^{14}$

W tragedii Faleńskiego dominującą postacią jest silnie zarysowana postać królowej Kalidonu, matki Meleagra. Althea pełni rolę dyrygentki i moderatorki całego przedstawienia. Ma świadomość, że w jej rękach leży egzystencja syna oraz zbiorowy los poddanych, którzy cierpią z powodu kary zesłanej na nich przez Artemidę. Urszula Kowalczuk, pisząc o motywacjach Faleńskiego przy wyborze scenerii do konstrukcji tragedii, zauważa:

Zwykle trudno jest jednoznacznie wskazać źródło mitologiczne. Najprawdopodobniej była nim w przypadku Althei utrwalona w powszechnej świadomości ma-

U. Kowalczuk, Felicjan Faleński. Twórczość i obecność, Warszawa 2002, s. 103-104. J. Kotarbiński, Pogrobowiec romantyzmu. Rzecz o Stanisławie Wyspiańskim, Warszawa 1909, s. 61.

M. Grzędzielska, Wstęp, w: F. Faleński, Wybór utworów, Wrocław 1971, s. LXXIX. 
tryca mitu łącząca w sobie cechy różnych jego wariantów. Doskonale znający klasyków Faleński pamiętał z pewnością wersję Homera w Iliadzie i Owidiusza w Przemianach, ale ich nie powielał. ${ }^{15}$

Istotnie, Faleński, konstruując Altheę, nie odwoływał się do określonego wzorca. Zdanie to podziela także Marek Dybizbański, pisząc o manifestacji antycznej struktury i wymowy tragedii w dziele Felicjana:

Podręcznikowo wyrazisty przykład rozwiniętej tragicznie namiętności przyniosła Althea Faleńskiego. Akcentując jej nie tylko formalną, lecz i światopoglądową zgodność z modelem tragedii antycznej, zasadzoną na niepodzielnym władaniu wyższej „konieczności”, Piotr Chmielowski dostrzegał podstawowy czynnik modernizacyjny w motywie spełniania się koniecznych wyroków jako skutku działań ludzkich namiętności. O psychologicznym przeistoczeniu mitu (w którego starożytnej wersji królowa Kalidonu spaliła głownię z zaklętym w niej życiem syna w akcie zemsty za zabicie swych braci podczas polowania na potwornego dzika, pustoszącego kraj z rozkazu rozgniewanej Artemidy) świadczy przesunięcie motywacyjnego środka ciężkości w stronę gniewu za uległą a nieodwzajemnioną miłość Meleagra do wojennej branki, królowej amazonek - Atalanty. ${ }^{16}$

Utwór staje się zatem syntezą różnych przekazów, wspartych ponadto diagnozami motywacji psychologicznych poszczególnych postaci, wypracowanymi przez samego Felicjana.

Trzeba podkreślić, że w Althei na pierwszy plan zostały wysunięte postaci kobiece. Najważniejsza jest bez wątpienia dumna i nieprzejednana królowa kalidońska Althea, która pała nienawiścią do amazonki i kochanki Meleagra - Atalanty. W tragedii występuje ponadto postać przybierającą kobiecą maskę; Empuza jest bytem tajemniczym, pojawiającym się nagle, odgrywa rolę wieszczki komentującej działania Althei i wskazującej możliwe konsekwencje podejmowanych przez nią decyzji.

Urszula Kowalczuk akcentuje również ważną pozycję, jaką zajmują bóstwa losu i zemsty oraz grecka bogini łowów, której poświęcone było królestwo Kalidonu: „W sposób szczególny została ukazana Artemida. Od jej woli zależą zdarzenia motywujące działania bohaterów, choć bogini nie pojawia się na scenie bezpośrednio. Obecna jest jako adresatka trzech hymnów do niej skierowanych" ${ }^{17}$. Warto dodać, że w całej tragedii Artemida występuje także pod imieniem Selene i Hekate. Selene zgodnie z mitologicznym przekazem była boginką Księżyca - tradycja rzymska określa ją mianem Luny. Hekate była zaś boginią czarnej magii i ciemności, a także pokuty i zemsty.

15 U. Kowalczuk, dz. cyt., s. 105.

16 M. Dybizbański, dz. cyt., s. 307.

17 U. Kowalczuk, dz. cyt., 105. 
Wspomniane bóstwa związane są wyraźnie z mitem lunarnym, który stanowił podstawę pierwotnych wierzeń i mitologii. Cykliczne pojawianie się i znikanie księżyca, a także jego oddziaływanie na pływy morskie kojarzono z ludzką egzystencją, która w istocie opiera się na pewnych uniwersalnych prawach przyrody. Bóstwa lunarne wspierały ponadto płodność i sferę seksualnych uniesień. Zastosowana przez Faleńskiego ewolucyjna zmienność bogini Artemidy buduje tragiczne napięcie, kształtując jednocześnie nieoczekiwane zwroty akcji i analogie sytuacyjne.

Poszczególne postaci oprócz cech fizycznych zostają obdarzone w Althei także określonym typem frazy. Królowa posługuje się pięciostopowym trochejem i dziesięciozgłoskowcem ${ }^{18}$. Wypowiedzi Althei mają rytm trocheiczny. Mowa Empuzy jest skomponowana poprzez zastosowanie sześciostopowego trocheja i dwunastozgłoskowca ${ }^{19}$. Charakter jej wypowiedzi nosi znamiona przestrogi i napomnienia. Atalanta wygłasza swoje krótkie przemowy pięciostopowym jambem ${ }^{20} \mathrm{i}$ jedenastozgłoskowcem. W polskiej metryce jamb jest trudną do zastosowania stopą. Faleński, ograniczając wypowiedzi Atalanty do minimum, chciał prawdopodobnie pokazać, że amazońska natura bohaterki nie pozwala jej na wygłaszanie kwiecistych i pełnych emocjonalnego tonu przemów. Rytm wiersza, którymi posługują się Empuza i Atalanta, wywołuje wrażenie muzyczności. Emocje wypływają z pełnych napięcia monologów Althei oraz stonowanych przemów Empuzy i Atalanty. Faleński, jak się zdaje, chciał uniknąć stonowanej frazy, na którą tak często narzekali krytycy w kontekście jego twórczości lirycznej ${ }^{21}$. Felicjan nie ograniczył jednak swojego zamysłu kompozycyjnego tylko do poszczególnych wersów, ale rozszerzył zróżnicowanie mowy na cały utwór, wyposażając wypowiedzi poszczególnych postaci w określony schemat rytmiczny i metryczny.

Faleński, zachowując strukturę greckiej tragedii, wprowadził na scenę chóry. Marek Dybizbański odnotowuje „sceniczną martwotę chórów Faleńskiego" w porównaniu z Meleagrem Wyspiańskiego; zauważa ponadto, że:

Poza tradycyjną funkcją i formą wypowiedzi chórów (dzielonych na strofy, antystrofy, epody) formalny klasycyzm Althei realizowała powściągliwość trzech (!) występujących bohaterek (Althei, Empuzy i Atalanty), jedność czasu, miejsca i akcji oraz przesunięcie za kulisy wszystkich scen drastycznych, czyli właściwie całej warstwy zdarzeń przeniesionej do relacji posłańca („Łowcy z gór”) - bardziej rygory-

M. Grzędzielska, Wstęp, s. LXXX.

Tamże, s. LXXX.

20 Tamże, s. LXXX.

Zob. P. Chmielowski, Nasza literatura dramatyczna, t. 2, Petersburg 1898. 
stycznie niż w późniejszej tragedii Wyspiańskiego (jakkolwiek i tam jedynym czynem spełnionym „na scenie” pozostaje spalenie głowni). ${ }^{22}$

W Althei występuje chór złożony z przedstawicieli ludu kalidońskiego, śpiewający hymny pochwalne i błagalne ku czci Artemidy. Bohaterom, wyłączając Empuzę, towarzyszą również „osobiste” chóry. Pojawia się także, podobnie jak w pieśniach dytyrambicznych, przewodnik chóru, będący kanałem porozumienia między bohaterami a społecznością. Poszczególne chóry śpiewają strofę i antystrofę. Epodę natomiast wykonuje ogół chórzystów.

Partie poprzedzające akcję zostały ujęte w charakterystyczny starogrecki model liryki chóralnej. Strofy połączone są zróżnicowanym układem rymów. Parzysta strofa odpowiada budową strofie poprzedzającej. W pierwszym wersie antystrofy mamy do czynienia z ośmiozgłoskowcem, $\mathrm{w}$ drugim i trzecim $\mathrm{z}$ jedenastozgłoskowcem, natomiast w czwartym - z pięciozgłoskowcem. Maria Grzędzielska zwraca uwagę, że Faleński nie stworzył imitacji czy też pastiszu tragedii”: „Althea jest inspirowana przez tradycję helleńską, lecz w artystycznej swobodzie stylizacji autor rozwiązywał własne problemy, pisał wariacje na temat mitu i wariacje formy tragedii, w której eksponował elementy monodyczne, polifoniczne i chóralne, słowem - muzyczne" ${ }^{23}$.

Warto podkreślić na marginesie, że muzyczna formuła organizacji tekstu literackiego nie była Felicjanowi obca, gdyż na kilka lat przed napisaniem Althei, poczynił parafrazę biblijnej opowieści do muzyki Stanisława Moniusz$\mathrm{ki}^{24}$. Trop muzyczny widoczny jest ponadto w Felicjanowym przekładzie Trenów Jeremiaszowych z 1902 roku ${ }^{25}$. Lamentacje są wyraźnie rytmizowane poprzez zastosowanie rymów żeńskich, głębokich oraz jedenastozgłoskowca ze stałą średniówką po piątej sylabie. Zbliża to wiersz Faleńskiego do tradycji śpiewów pasyjnych, związanych z obchodami Triduum Paschalnego. Chodzi oczywiście o Ciemne Jutrznie (Officium tenebrarum), które z biegiem lat zyskiwały bardzo bogatą oprawę muzyczną. Partie lamentacyjne wykonywały chóry oraz soliści przy akompaniamencie muzycznym, dlatego dbałość o ich formę, ułatwiającą oratoryjne wykonanie, była kluczową sprawą.

Nie tylko muzyczność, ale też sposób kreacji postaci zbliża tragedię Felicjana do oratorium. Jak zauważa Marek Dybizbański, od klasycznej formy oratoryjnej oddala $\mathrm{z}$ kolei Altheę wyeksponowanie wątku dramatycznego ${ }^{26}$

M. Dybizbański, dz. cyt., s. 308.

M. Grzędzielska, dz. cyt., s. LXXXI.

Tamże.

Zob. Felicjan [F. Faleński], Przekłady z Pisma Starego Zakonu, Warszawa 1902.

M. Dybizbański, dz. cyt., 308. 
oraz silna indywidualizacja w kreacjach bohaterów. Badacz zestawia pod tym względem Althę̨ z Meleagrem Wyspiańskiego:

[...] Faleński komponował oratoryjny dramat wewnętrznych zmagań bohaterki w starciu z bogami, uzbrojonej w miłość i dumę, pokonanej przez utratę oręża przemienionego w upokorzenie i nienawiść, a Wyspiański konstruował tragedię nastrojową, której bohaterowie „nie znają prawdziwej istoty swych działań” i ulegając raczej niejasnym przeczuciom zagłady niż racjonalnie rozpoznanej zasadzie działania transcendentalnych sił, zbliżają Meleagra do symbolicznej dramaturgii Maeterlinc$\mathrm{ka}$, oddalając go od modelu realizowanego w tragediach parnasisty de Lisle'a. ${ }^{27}$

Warto podkreślić, że w Althei warstwa leksykalna została niejako uzupełniana przez meliczny charakter wypowiadanych fraz. Wprowadzenie do tragedii stanowi hymn ku czci Artemidy. Śpiew chóru jest natomiast wprowadzeniem do pierwszego epizodu. Akcję rozpoczyna pojawienie się na scenie królowej Kalidonu, która, drwiąc z poddanych, nawołuje do nieustępliwości wobec nieprzychylnej Artemidy:

\footnotetext{
Precz stąd, nędzni! Czyż widziano kiedy,

By pokorą sam wdeptywał w ziemię

Cześć swą twardy Kalydonu lud? [...]

W oczach przekleństw błysk, milczenie wzgardy -

Oto godny człeka bój śmiertelny

Z bogów złych przemocą nieśmiertelną!
}

(s. $283-284)^{28}$

Althea, bluźniąc przeciw bogom, wspomina ponadto swojego ukochanego syna Meleagra, przypominając ludowi jego męstwo i zasługi. Faleński nie wprowadza jednak postaci królewicza na scenę. Poczynania Meleagra są relacjonowane przez poszczególne postaci dramatu. Obecność męskich postaci została $\mathrm{w}$ tragedii ograniczona do koniecznego minimum. Felicjan nie wspomina chociażby o władcy Kalidonu - Ojneusie. Jedynym mężczyzną, który wypowiada swoje kwestie, jest Łowca z gór, relacjonujący obraz zniszczeń dokonanych przez dzika Artemidy. Mężczyzna mówi także o poczynaniach wojennych młodego królewicza. [Faleński], organizując hymniczną warstwę tragedii, posłużył się ciekawym zabiegiem, o którym Urszula Kowalczuk, pisze: „Sfunkcjonalizował [Faleńśki] hymny chóru w ten sposób, że nie tylko przypominają o gniewie bogini, ale mówią o skutkach jej działań z perspektywy ludzi, by wreszcie przekształcić się w uniwersalną

27 Tamże, s. 308.

28 Wszystkie cytaty z Althei lokalizuję w tekście głównym za przywoływanym już wydaniem Wyboru utworów Faleńskiego w opracowaniu Marii Grzędzielskiej. 
refleksję egzystencjalną" ${ }^{29}$. W hymnach odnoszących się do kolejnych wcieleń Artemidy diagnozy dotyczące bytu i bycia zostają tragicznie pogłębione, wywołując poczucie grozy i zwątpienia.

Bardzo ważna dla wymowy ideowej tragedii jest kreacja Althei. Jej pozorna siła tkwi w przekonaniu, że jest ona strażniczką życia syna oraz odpowiada za jego wszelkie decyzje, które w istocie rzeczy muszą być zbieżne z jej oczekiwaniami:

\author{
Wola moja prawem jest jedynym. \\ Tak - dopóki zechcę - chcieć zaś umiem - \\ Meleager nieśmiertelnym będzie! \\ Nawet gdyby sam chciał umrzeć - ani \\ Myśleć o tym mu beze mnie! \\ Bom ja matka, jak nie było drugiej - \\ Której miłość nieśmiertelność dawa, \\ Bom kobieta, jakiej świat nie widział - \\ Której dość jest chcieć, by zadać śmierć!
}

(s. 287)

Irracjonalna wola, budząca skojarzenie z teorią Schopenhauera, stanowi dla Althei prawo. Wszelkie działania zostają wyprowadzone właśnie z woli, wpływającej na przebieg zdarzeń i oddziałującej na losy bohaterów. Warto w tym kontekście przywołać opinię Urszuli Kowalczuk, która pisząc o pozornej sile psychiki kalidońskiej królowej, zauważa:

Kreacja Althei jest dość monolityczna. Jej dumne złorzeczenia nie mają tyle energii, którą zyska tragiczne wołanie towarzyszące rozpoznaniu prawdy, że wolność od boskich norm jest wolnością do zbrodni. [...] Zrównujący Altheę z bogami dar decydowania o życiu syna okazuje się przekleństwem, gdy nienawiść i urażona duma każą jej zadać mu śmierć ${ }^{30}$.

Można zatem dostrzec, że Althea zapowiada egzystencjalną problematykę wyrażoną w dojrzałej twórczości Felicjana (Meandry), piętnującej pychę i pozorne przekonanie o własnej wyższości.

Pojawienie się Empuzy, tajemniczej przedstawicielki ludu kalidońskiego, której status ontologiczny trudno określić, jest zapowiedzią powolnego upadku Althei. Nie do końca wiadomo, czy Empuza to demon, wampir czy może potwór. Ma ona bez wątpienia pewną misję do wykonania i jest swego rodzaju lustrem dla Althei, w którym odbija się jej tragiczna egzystencja. Empuza poucza przecież królową, że zazdrośni bogowie prędzej czy później upomną się o dobro, które w danym momencie jest pozornie we władaniu

U. Kowalczuk, dz. cyt., s. 106

30 Tamże, s. 108. 
człowieka. Moment ten najczęściej przychodzi nieoczekiwanie i staje się przyczyną klęski bohatera:

Któryż z bogów chętnie z władzy swej się wyzuł

Lub z rąk wytrąconą wziąć bezkarnie dał?

Jest w ich ręku grom - są zazdrosne, mściwe -

Wolno ich nie kochać - lecz się bać ich trzeba!

(s. 289)

Empuza w toku trwania akcji dramatycznej wskazuje że Althea powinna lękać się swej domniemanej boskiej natury, która zaprowadzi ją przecież do zbrodni. Przerażające dla królowej wróżby wyraźnie wskazują, że Meleager zdradził matczyną miłość i sprzeniewierzył się jej woli. Mówiąc o miłości jako domenie ludzi słabych, Empuza wskazuje, że to uczucie przynależy zwykłym śmiertelnikom szukającym pewnej stabilizacji życiowej. Przypomnijmy, że Althea dostrzegała przecież w sobie boską iskrę, gardząc poddańczą uczuciowością. Oznacza to, że sama zaprzecza swojej filozofii życiowej, wypowiadając pełne napięcia słowa: „Macierzyńskie wnętrze sercem jest” (s. 290). Ale przywołane przez bohaterkę matczyne serce w wyniku działań Empuzy zaczynają przepełniać obawy i wątpliwości. Althea dostrzega w Empuzie uosobione zło, które kusi ją i zwodzi niczym zły duch. Urszula Kowalczuk, analizując portret wizjonerki, pisze: „Lęk Empuzy i bojaźń chóru gwarantują im dotarcie do istoty zdarzeń. Kreacja Empuzy jest bardzo wyrazista. To postać, którą obdarzył Faleński własnymi dylematami niepokoju myślenia" ${ }^{31}$. Pełne zrozumienie własnej istoty, zdaniem Felicjana, jest możliwe tylko wtedy, gdy zagłębimy się w swoje wnętrze i dokonamy pełnej eksploracji przyrodzonej osobowości, nawet jeśli okaże się ona przerażająca.

Egzystencja Meleagra w tragedii Faleńskiego, modelowana wolą matki, stanowi tylko imaginację jednostkowej wolności. W istocie miał być to przecież idealny los, pozbawiony przypadkowości i w pełni przewidywalny. Althea zapomniała jednak o sile innego rodzaju miłości. Czym innym jest miłość do matki, a czym innym uczucie do wybranki serca. Meleager, nie bacząc na konsekwencje, zachowuje się jak romantyczny kochanek. Magnetyzm serca nakazuje mu trwać przy gardzącej mężczyznami Atalancie, która w oczach Althei urasta do rangi głównej rywalki potrafiącej tylko „prężyć amazoński łuk”. Decyzja królowej motywowana jest chęcią, jak pisze Maria Grzędzielska, „unicestwienia zdegradowanego przedmiotu miłości i dumy” ${ }^{32}$. Postacią tragiczną jest ponadto Empuza, która w przeciwieństwie do innych postaci 
dramatu, nie ma uczuć. Na psychoanalityczny trop interpretacyjny tragedii Faleńskiego, zwraca uwagę Urszula Kowalczuk, pisząc:

Faleński tak przeformułował mitologiczną fabułe, że jej najważniejsze znaczenia skupiają się w Althei nie wokół zbrodni, lecz dotyczą problematyki sensu istnienia. Winę Althei można więc postrzegać nie tylko w kategoriach buntu, ale przede wszystkim jako zlekceważenie praw życia. Tytułowa bohaterka często bywa przeciwstawiana Empuzie. Felicjan pokazuje Altheę-matkę i Empuzę, której przekleństwem jest nigdy matką nie być. Pierwsza nie zna najważniejszych wartości i dlatego ma dumę pogardy. Druga, obdarzona szczególną świadomością, jest wciąż niepewna i niespokojna. Antynomiczność obu bohaterek wyznaczona jest przez odmienne sposoby doświadczania egzystencji. Podlegająca emocjom Althea pozbawiona została możliwości rozumiejącego ogarnięcia zdarzeń, w których uczestniczy. Empuza natomiast posiada nadmiar wieszczej wiedzy, ale skazana jest na uczuciową pustkę i obojętność. Obie są nieszczęśliwe, rozdarte i zagubione. ${ }^{33}$

W tragedii Faleńskiego Althea byłaby w stanie wybaczyć synowi zamordowanie swoich braci czy nawet zdradę ojczyzny. Nie mogła jednak pogodzić się z faktem, że pozbawiona dziewiczych wdzięków kobieta przyczyniła się do upodlenia jej syna i zerwania synowsko-matczynej więzi. Meleager, mając świadomość winy tragicznej, wolał jednak umrzeć, zaznając siły prawdziwego uczucia, niż egzystować w teatrze losu, którego reżyserem miała być zawsze Althea.

Z całą pewnością można stwierdzić, że tragedia Faleńskiego Althea przyniosła nową jakość w repertuarze dziewiętnastowiecznej dramaturgii. Zachowując elementy strukturalne antycznej tragedii, Felicjan zdobył się na wykorzystanie warstwy mitologicznej do stworzenia dzieła będącego psychologiczną analizą motywacji bohaterów. Eksponowanie przeżyć wewnętrznych postaci i zderzanie ich zamierzeń z planem boskim wysuwa na pierwszy plan religijny i etyczny charakter tego utworu. Gdyby nie wartka akcja dramatyczna i mocno zarysowane psychologiczne kreacje bohaterów moglibyśmy uznać Altheę za wybitne oratorium, czekające tylko na muzyczny akompaniament. Niemniej jednak przeplatanie się partii chóralnych i solowych, religijno-egzystencjalna tematyka i wewnętrzne uporządkowanie warstwy językowo-brzmieniowej utworu zbliżają go do wielkiej formy muzycznej, mającej swoje źródła w epoce baroku. Innowacyjność Faleńskiego na polu tragedii dziewiętnastowiecznej docenia także Marek Dybizbański, pisząc:

Byłoby jednak oczywiście błędnym mniemanie, że dopiero Wyspiański miał w czym wybierać. Faleńskiemu w 1875 roku bogaty repertuar gotowych środków podsunąć mógł zarówno przedromantyczny klasycyzm (mimo swej przestarzałości

U. Kowalczuk, dz. cyt., s. 110-111. 
obecny w krytycznej refleksji), historiozoficzny i widowiskowy antyk romantyków (zręcznie przez autora Althei podejmowany w dramatach „rzymskich”), a także objawiający się w poezji od lat kilkunastu zwrot ku starożytności rzymskiej, a przede wszystkim greckiej, bliższy filozoficznej postawie niemieckich hellenistów niż parnasistowskiemu estetyzmowi. ${ }^{34}$

Althea stawowi manifestację światopoglądu Felicjana oraz jest świadectwem jego zainteresowań i bliskości ideowej z antykiem grecko-rzymskim. Trudność w dokładnym sprecyzowaniu gatunku, jakim posłużył się Faleński, może świadczyć o wybitnej dojrzałości literackiej pisarza na polu dramatu dziewiętnastowiecznego, gdyż, jak zauważa Maria Grzędzielska: „[...] w artystycznie swobodnej stylizacji autor rozwiązywał własne problemy, pisał wariacje na temat mitu i wariacje formy tragedii, w której eksponował elementy monodyczne, polifoniczne i chóralne, słowem - muzyczne" ${ }^{35}$.

\author{
eristo \\ Łukasz Tupacz (Cardinal Stefan Wyszyński University in Warsaw) \\ e-mail: lukasz.tupacz@gmail.com \\ "Althea" of Felicjan Faleński - \\ Between Nineteenth-CENTURy Drama and Oratorio
}

A B S T R AC T

The article is an attempt at analyzing the tragic formula of Felicjan Faleński with a special focus on the musical layer that brings Althea closer to the oratory. The mythological story of the Calidonian hunts was used by Faleński only to constitute the background of the indepth psychological analysis of the heroes. Althea, retaining the structural elements of the Greek tragedy, is closer to modernist worldview diagnoses that focus on the sphere of the human psyche and entangle humanity in the will of power, the instinct that determines all actions and existence.

\title{
K E Y W O R D S
}

Felicjan Faleński, musicality, oratory, psychology, tragedy 